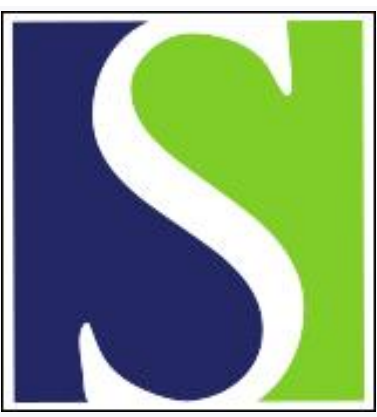

Scand J Work Environ Health 2012;38(5):418-426

https://doi.org/10.5271/sjweh.3268

Published online: 10 Jan 2012, Issue date: 01 Sep 2012

With long hours of work, might depression then lurk? A nationwide prospective follow-up study among Danish senior medical consultants

by Varma A, Marott JL, Stoltenberg CDG, Wieclaw J, Kolstad HA, Bonde $J P$

Affiliation: Department of Occupational and Environmental Medicine, Bispebjerg Hospital, Bispebjerg Bakke 23, DK-2400 Copenhagen, Denmark. anshu.varma@regionh.dk

Refers to the following texts of the Journal: 2003;29(4):317-324 2007;33(2):105-113 2007;33(5):344-350

The following articles refer to this text: 2013;39(5):515-520; 2016;42(2):153-161; 2018;44(3):239-250

Key terms: anti-depressive drug; Denmark; depression; long work hour; medical consultant; mental health; prospective study; work hour; working time; worktime

This article in PubMed: www.ncbi.nlm.nih.gov/pubmed/22234431 


\title{
With long hours of work, might depression then lurk? A nationwide prospective follow-up study among Danish senior medical consultants
}

\author{
by Anshu Varma, Cand scient san publ, ${ }^{1}$ Jacob Louis Marott, Cand scient stat, ${ }^{1}$ Christian Ditlev Gabriel \\ Stoltenberg, Cand scient san publ, ${ }^{1}$ Joanna Wieclaw, PhD, Cand psych, ${ }^{2}$ Henrik Albert Kolstad, PhD, \\ $M D,^{2}$ Jens Peter Bonde, PhD, MD ${ }^{1}$
}

Varma A, Marott JL, Stoltenberg CDG, Wieclaw J, Kolstad HA, Bonde JP. With long hours of work, might depression then lurk? A nationwide prospective follow-up study among Danish senior medical consultants. Scand J Work Environ Health. 2012;38(5):418-426. doi:10.5271/sjweh.3268

\begin{abstract}
Objective The aim of this study was to examine depression as a potential negative health effect of long work hours, anticipating an exposure-response relationship.

Method A nationwide prospective cohort study of 2790 Danish senior medical consultants was conducted (61.7\% response rate). With the consent of Danish Data Protection Agency, data from a questionnaire survey was linked with data from a Medical Products Agency Register. Long work hours were defined based on a selfreported average of weekly work hours $>40$, while redemption of anti-depressive (AD) drug prescriptions defined depression. Proportional hazards Cox regression analyses were conducted adjusting for gender, age, marital status, medical specialty, decision authority at work, work social support, quantitative work demands, and AD drugs prescribed before baseline.

Results Long weekly work hours did not increase the risk of redeeming AD drug prescriptions at all times during follow-up compared to the reference of 37-40 work hours [41-44 hours: hazard ratio (HR) $0.95,95 \%$ confidence interval $(95 \%$ CI) $0.5-1.8$; $45-49$ hours: HR 0.88, 95\% CI 0.4-1.8; 50-54 hours: HR 0.83, 95\% CI 0.3-2.1; 55-59 hours: HR 0.67, 95\% CI 0.2-2.9; $\geq 60$ hours: HR 0.48, 95\% CI 0.1-3.7]. The same result emerged when work hours was applied in a continuous form (from 25-36 hours to 37-40 hours to 41-44 hours and so on) (HR $0.93,95 \%$ CI 0.76-1.13) and when robust analyses were conducted (data not shown).
\end{abstract}

Conclusions This study does not support the anticipation that long work hours increase the risk of depression. If anything, long work hours vaguely appear to decrease the risk of redeeming AD drug prescriptions.

Key terms anti-depressive drug; mental health; prospective study; work hour; working time; worktime.

Long work hours may confer a strain that is detrimental to health (1-8). A potential negative health effect of long work hours is the risk of depression (9-25). It has been suggested that working long hours could result in sleep deprivation, lack of recovery from work, reduced time for non-work activities, injuries, and longer exposure to work demands and workplace hazards (1). These immediate consequences might develop into depression by means of fatigue, negative mood due to lack of time for socialization, reduced joy of work and life in general due to injuries, and unwanted feelings towards work because of increased exposure to workplace demands and hazards.
Earlier studies have implied a potential relationship between long work hours and depression (9-25), but several limitations preclude causal inference: (i) the application of a cross sectional study design in the majority of the studies (11-17) disguises the direction of association between long work hours and depression; (ii) the low response rates, ranging from $35-58 \%$, (9-13, $15,18,19)$ increase the risk of selection bias; (iii) self-reporting of exposure (9-25) and outcome (9-21, 23-25) could lead to unreliable responses from respondents when the memory reference periods are demanding or questions trigger socially desirable answers; (iv) lack of sufficient contrast in work hours $(10,12-15$,

1 Department of Occupational and Environmental Medicine, Bispebjerg Hospital, Copenhagen, Denmark.

2 Department of Occupational and Environmental Medicine, Aarhus University Hospital, Aarhus, Denmark. 
$17-20,22,24)$ hinders identification of a potential exposure-response relationship; (v) the definition of depression is unspecific or depression and anxiety are measured as one entity $(9,11,14,17,19,22)$. Either way, it becomes difficult to know whether depression is actually being measured and creates doubt concerning what the outcome really represents; (vi) with the exception of two studies $(13,24)$ none of the studies include or report modifying factors, providing a rather simple image of the relationship between long work hours and depression; and (vii) the follow-up participation is not described in the cohort studies with one exception (24). As a result, it is difficult to characterize possible bias. All in all, clarity on the relationship between long work hours and depression is still needed.

The main objective of the present study is to examine long work hour practices in relation to depression in a homogeneous group of employees with a wide span of weekly work hours. The anticipation is that long work hours increase the risk of developing depression and that the risk increases simultaneously with the number of hours worked above standard work hours. The study was designed to ameliorate some but not all limitations of earlier studies.

\section{Methods}

\section{Population and data collection}

From April-October 2008, members of the Danish Association for Senior Medical Consultants $(\mathrm{N}=4520)$ were encouraged to participate in an internet-based self-administered questionnaire survey addressing work conditions of senior medical consultants primarily employed in hospitals. After three reminders, a response rate of $61.7 \%$ was obtained.

Work hour information was retrieved by means of the item: "How many hours do you work a week on average (main occupation)?" Response categories were: 25-36, 37-40, 41-44, 45-49, 50-54, 55-59, and $\geq 60$ hours. A fulltime work week in Denmark is $37-40$ hours. Hence, senior medical consultants working $>40$ hours a week on average were considered as having long work hours; $37-40$ hours a week on average represented the reference work week.

In 2010, data was obtained on the expedition date for redemption of anti-depressive (AD) drug prescription at a Danish pharmacy from the Medical Products Agency Register covering the period 1995-2009. The Medical Products Agency Register classifies prescribed drugs according to the Anatomical Therapeutic Chemical Classification System at the level of the generic pharmaceutical (ATC codes). Redeemed prescription of
N06AA, N06AB, N06AX, N06AF, N06AG, and N06X after the date of entry into the study was considered as a proxy for clinical depression.

The senior medical consultants were followed from their study entry date in 2008 until the end of 2009. Linkage of data from the questionnaire survey with the the Medical Products Agency Register took place with consent from the Danish Data Protection Agency. Statistics Denmark carried out the data linkage and ensured anonymity by detaching personalized identifiers before the data was made accessible for analysis. Two eligibility criteria were (i) non-missing data on work hours and (ii) no redemption of $\mathrm{AD}$ drug prescriptions nine months before study entry in order to exclude prevalent cases of depression at baseline. The choice of nine months was based on the fact that most depressed persons recover after six months to one year (26).

Gender, age, marital status, medical specialty, decision authority at work, social support at work, quantitative work demands and previous redemption of AD drug prescription (tables 1 and 2) were included as potential confounders. The following factors were considered as modifiers of the effect of long work hours on depression: (i) female workers with long work hours [may be predisposed to being diagnosed with depression compared to male workers with long work hours since women visit a doctor more often than men (27)]; (ii) older workers (are expected to have more work experience than younger workers because they have a longer work history and, therefore, may have a greater tolerance threshold towards the negative effects of long work hours); (iii) married workers (could be at lower risk of developing depression than unmarried, widowed, or divorced workers if being married is considered as a form of support able to buffer the potential negative effect of working long hours); (iv) working long hours in medical specialties with exposure to difficult emotional situations (might enhance the risk of developing depression compared to working long hours in medical specialties where emotional demanding situations are less common); (v) workers with long work hours and high quantitative work demands (for instance time pressure may result in higher risk of depression); (vi) decision authority and social support at work [justified for by means of Robert Karasek's Demand Control Model (28)].

Data on all variables was retrieved from Statistics Denmark, the questionnaire survey, or the Medical Products Agency Register. Decision authority at work, social support at work, and quantitative work demands were all measured with scales. Decision authority was defined with four questions: "Do you have great influence on decisions concerning your work?", "Do you have influence on who you work together with?", "Do you have influence on the amount of your work?", and "Do you 
Table 1. Characteristics of senior medical consultants by work hours, categorical variables. [AD=anti-depressive.]

\begin{tabular}{|c|c|c|c|c|c|c|c|c|c|c|c|c|c|c|c|c|}
\hline \multirow[t]{3}{*}{ Characteristic } & \multirow[b]{3}{*}{$\mathrm{N}=2790$} & \multirow[b]{3}{*}{$\%$} & \multicolumn{14}{|c|}{ Work hours } \\
\hline & & & \multicolumn{2}{|c|}{$\begin{array}{c}25-36 \\
(N=126)\end{array}$} & \multicolumn{2}{|c|}{$\begin{array}{c}37-40 \\
(\mathrm{~N}=888)\end{array}$} & \multicolumn{2}{|c|}{$\begin{array}{c}41-44 \\
(\mathrm{~N}=743)\end{array}$} & \multicolumn{2}{|c|}{$\begin{array}{c}45-49 \\
(N=569)\end{array}$} & \multicolumn{2}{|c|}{$\begin{array}{c}50-54 \\
(N=260)\end{array}$} & \multicolumn{2}{|c|}{$\begin{array}{c}55-59 \\
(N=121)\end{array}$} & \multicolumn{2}{|c|}{$\begin{array}{c}\geq 60 \\
(\mathrm{~N}=83)\end{array}$} \\
\hline & & & $\mathrm{N}$ & $\%$ & $\mathrm{~N}$ & $\%$ & $\mathrm{~N}$ & $\%$ & $\mathrm{~N}$ & $\%$ & $\mathrm{~N}$ & $\%$ & $\mathrm{~N}$ & $\%$ & $\mathrm{~N}$ & $\%$ \\
\hline \multicolumn{17}{|l|}{ Gender } \\
\hline Men & 1977 & 70.9 & 93 & 73.8 & 639 & 72 & 508 & 68.4 & 397 & 69.8 & 191 & 73.5 & 86 & 71.1 & 63 & 75.9 \\
\hline Women & 813 & 29.1 & 33 & 26.2 & 249 & 28 & 235 & 31.6 & 172 & 30.2 & 69 & 26.5 & 35 & 28.9 & 20 & 24.1 \\
\hline \multicolumn{17}{|l|}{ Marital Status } \\
\hline Married & 2296 & 82.3 & 104 & 82.5 & 724 & 81.5 & 602 & 81 & 478 & 84 & 216 & 83.1 & 102 & 84.3 & 70 & 84.3 \\
\hline Unmarried & 165 & 5.9 & 11 & 8.7 & 52 & 5.9 & 51 & 6.9 & 32 & 5.6 & 12 & 4.6 & 6 & 5 & 1 & 1.2 \\
\hline Divorced & 259 & 9.3 & 8 & 6.3 & 86 & 9.7 & 77 & 10.4 & 48 & 8.4 & 25 & 9.6 & 8 & 6.6 & 7 & 8.4 \\
\hline Widow/widower & 35 & 1.3 & 2 & 1.6 & 10 & 1.1 & 5 & 0.7 & 7 & 1.2 & 4 & 1.5 & 3 & 2.5 & 4 & 4.8 \\
\hline Missing values & 35 & 1.3 & 1 & 0.8 & 16 & 1.8 & 8 & 1.1 & 4 & 0.7 & 3 & 1.1 & 2 & 1.7 & 1 & 1.2 \\
\hline \multicolumn{17}{|l|}{ Work specialty } \\
\hline Internal medicine & 1187 & 42.5 & 40 & 31.8 & 354 & 39.9 & 301 & 40.5 & 265 & 46.6 & 119 & 45.8 & 60 & 49.6 & 48 & 57.8 \\
\hline Surgery & 798 & 28.6 & 30 & 23.8 & 257 & 28.9 & 227 & 30.5 & 167 & 29.3 & 67 & 25.8 & 33 & 27.3 & 17 & 20.5 \\
\hline Psychiatry & 361 & 12.9 & 31 & 24.6 & 145 & 16.3 & 88 & 11.8 & 49 & 8.6 & 27 & 10.4 & 12 & 9.9 & 9 & 10.8 \\
\hline Laboratory testing & 238 & 8.5 & 14 & 11.1 & 63 & 7.1 & 64 & 8.6 & 53 & 9.3 & 31 & 11.9 & 10 & 8.3 & 3 & 3.6 \\
\hline Missing values & 206 & 7.4 & 11 & 8.7 & 69 & 7.8 & 63 & 8.5 & 35 & 6 & 16 & 6 & 6 & 5 & 6 & 7.2 \\
\hline \multicolumn{17}{|c|}{$\begin{array}{l}\text { Previous redemption } \\
\text { of } A D \text { drug prescription }\end{array}$} \\
\hline Yes & 308 & 11 & 18 & 14.3 & 92 & 10.4 & 79 & 10.6 & 72 & 12.7 & 29 & 11.2 & 10 & 8.3 & 8 & 9.6 \\
\hline No & 2482 & 89 & 108 & 85.7 & 796 & 89.6 & 664 & 89.4 & 497 & 87.3 & 231 & 88.8 & 111 & 91.7 & 75 & 90.4 \\
\hline
\end{tabular}

Table 2. Characteristics of senior medical consultants by work hours, continuous variables. [SD=standard deviation; Min=minimum; Max=maximum.]

\begin{tabular}{|c|c|c|c|c|c|c|c|c|c|c|c|c|c|c|c|c|c|c|c|c|}
\hline \multirow[t]{3}{*}{ Characteristic } & \multirow[b]{3}{*}{$\mathrm{N}=2790$} & \multirow[b]{3}{*}{$\%$} & \multirow[b]{3}{*}{ Mean } & \multirow[b]{3}{*}{ SD } & \multirow[b]{3}{*}{ Min } & \multirow[b]{3}{*}{ Max } & \multicolumn{14}{|c|}{ Work hours } \\
\hline & & & & & & & \multicolumn{2}{|c|}{$\begin{array}{c}25-36 \\
(N=126)\end{array}$} & \multicolumn{2}{|c|}{$\begin{array}{c}37-40 \\
(\mathrm{~N}=888)\end{array}$} & \multicolumn{2}{|c|}{$\begin{array}{c}41-44 \\
(N=743)\end{array}$} & \multicolumn{2}{|c|}{$\begin{array}{c}45-49 \\
(\mathrm{~N}=569)\end{array}$} & \multicolumn{2}{|c|}{$\begin{array}{c}50-54 \\
(\mathrm{~N}=260)\end{array}$} & \multicolumn{2}{|c|}{$\begin{array}{l}55-59 \\
(\mathrm{~N}=121)\end{array}$} & \multicolumn{2}{|c|}{$\begin{array}{l}\geq 60 \\
(\mathrm{~N}=83)\end{array}$} \\
\hline & & & & & & & Mean & SD & Mean & SD & Mean & SD 1 & Mean & SD 1 & Mean & SD & Mean & SD & Mean & SD \\
\hline Age & 2790 & 100 & $54.5^{a}$ & $43.4^{b}$ & 36 & 80 & 54.7 & 7 & 55 & 6.5 & 54.4 & 6.5 & 54.2 & 6.4 & 55.2 & 6.9 & 54.4 & 7 & 56.6 & 6.2 \\
\hline Follow-up (days) & 2790 & 100 & $569^{a}$ & $6363^{b}$ & 2 & 584 & 508.2 & 89.4 & 527.6 & 79.9 & 524.6 & 83.3 & 531.9 & 71.2 & 532.3 & 80.4 & 529.4 & 85.7 & 536 & 71.2 \\
\hline $\begin{array}{l}\text { Decision } \\
\text { authority at work }\end{array}$ & 2732 & 97.9 & 3.3 & 0.8 & 1 & 5 & 3.3 & 0.8 & $3 \quad 3.2$ & 0.9 & 3.3 & 0.8 & 3.3 & 0.7 & 3.4 & 0.8 & 3.5 & 0.7 & 3.7 & 0.8 \\
\hline Missing values & 58 & 2.1 & & & & & & & & & & & & & & & & & & \\
\hline $\begin{array}{l}\text { Social support } \\
\text { at work }\end{array}$ & 2692 & 96.5 & 3.4 & 1 & 1 & 5 & 3.4 & 1.1 & 3.5 & 1.1 & 3.4 & 1 & 3.4 & 1 & 3.3 & 1 & 3.3 & 1 & 3.3 & 1.1 \\
\hline Missing values & 98 & 3.5 & & & & & & & & & & & & & & & & & & \\
\hline $\begin{array}{l}\text { Quantitative work } \\
\text { demands }\end{array}$ & 2726 & 97.7 & 3.2 & 0.8 & 1 & 5 & 2.7 & 0.9 & 2.9 & 0.8 & 3.2 & 0.7 & 3.4 & 0.7 & 3.6 & 0.7 & 3.5 & 0.6 & 3.6 & 0.8 \\
\hline Missing values & 64 & 2.3 & & & & & & & & & & & & & & & & & & \\
\hline
\end{tabular}

have influence on what you do at your work?". Social support was defined by two questions: "If you have problems at your work, is it then possible to (i) "Get the necessary help and support from your management?" and (ii) "Get the necessary help and support from your own colleagues?". Quantitative work demands was covered by the following questions: "Is your work unevenly distributed so that it builds up?", "How often is it that you do not have time for all of your working tasks?", "Do you fall behind with your work?", and "Do you have enough time for your working tasks?”. Scale scores were mean scores.
The higher the mean score, the larger the experience of decision authority and social support and the smaller the experience of quantitative work demands. Tables 1 and 2 provide information on the coding of remaining variables. The data collection process and stepwise actions are depicted in figure 1.

\section{Statistical analysis}

Statistical analyses were performed with SAS version 9.1 (SAS Institute, Cary, NC, USA) and R (R version 


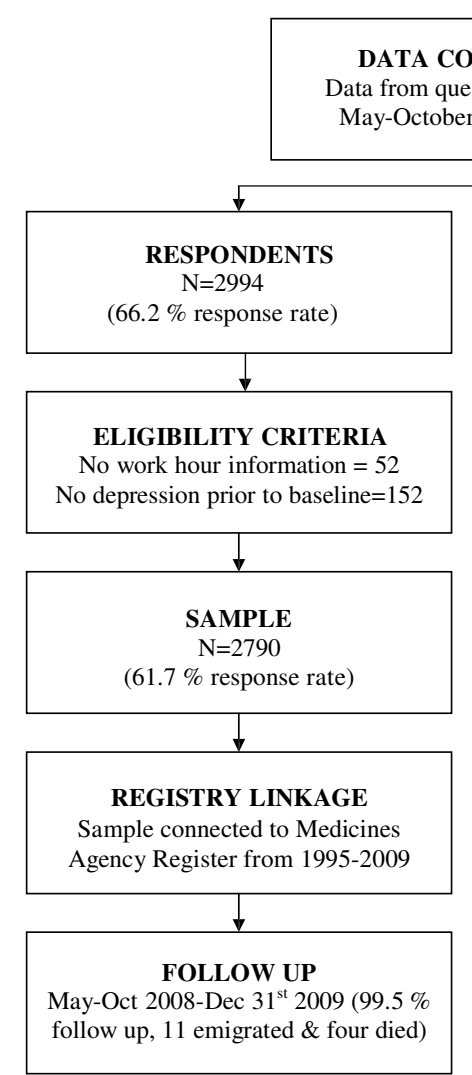

Figure 1. Flowchart illustrating actions and results in the data collection process.

2.11.1). Proportional hazards Cox regression analyses with delayed entry were applied. Follow-up time served as the time axis. Observations were censored at first expedition date of redemption of $\mathrm{AD}$ drug prescription during follow-up, death, emigration, or study end, whichever came first.

The modeling of observations was based on crude and adjusted measurements. Each modifier was included in the adjusted model and then excluded one at a time after having observed its potential effect.

To assess the robustness of the results obtained from the adjusted model, two analyses were made. The first analysis was on senior medical consultants without any history of previous redemption of AD drug prescriptions. The second analysis was based on the criteria that senior medical consultants redeemed more than one AD drug prescription.

In order to uncover any potential problems with representativeness, descriptive univariate analyses were made on senior medical consultants who did not participate in the study, so-called "non-respondents". This non-response analysis was supplemented by descriptive univariate analyses comparing "initial respondents" (medical consultants who responded by means of the online questionnaire) with "late respondents" (medical consultants who received the questionnaire on paper after several reminders) on variables where information from non-respondents was not available. Late respondents are considered to behave more like non-respondents and therefore such a supplementary comparison could also indicate problems with representativeness.

Model assessments were made by checking fulfillment of linearity and proportional hazards assumptions with Martingale \& Schonefeld residuals.

\section{Results}

The majority of the senior medical consultants had long work hours. In general, the senior medical consultants were male, middle aged, married, primarily working with internal medicine, and had not previously redeemed AD drug prescriptions. On average, the senior medical consultants reported moderate amounts of decision authority at work, social support at work, and quantitative work demands. They were followed for more than a year and a half on average (tables 1 and 2). Long work hours were more common among initial than late respondents, and non-respondents had a higher redemption of $\mathrm{AD}$ drug prescriptions than respondents (see Appendix with tables A and B). 
Main results showed that long weekly work hours did not increase the risk of redeeming AD drug prescriptions at all times during follow-up compared to the reference work week of 37-40 hours. Instead, long weekly work hours vaguely appeared to decrease the risk of redeeming AD drug prescriptions (table 3 ). The assumption of linearity for all the continuous variables and the proportional hazards assumption were fulfilled (data not shown).

In order to enable efficient analyses of modifiers and result robustness, work hours was applied in a continuous form (from 25-36 hours to 37-40 hours to 41-44 hours and so on) since an adjusted Cox regression analysis with work hours as a continuous variable (table 4) showed the same result as observed in the adjusted Cox regression analysis with work hours as a categorical variable. The linearity assumption and proportional hazards assumption were fulfilled for the adjusted Cox regression analysis with work hours as a continuous variable (data not shown). Decision authority and social support at work, quantitative work demands, and medical specialty indicated potential for modifying the effect of long work hours on redemption of AD drug prescriptions (table 5). Model assessments were successful (data not shown). The analyses of result robustness showed the same trend as observed in the adjusted Cox regression analysis with work hours as a categorical variable and work hours as a continuous variable. Model assessments were successful (data not shown).

\section{Discussion}

Senior medical consultants compared to Danish citizens

Long work hours are more common among the senior medical consultants than the general Danish working population. In the latter, $36.4 \%$ worked $>37$ hours a week on average in 2008 (32) compared to $81 \%$ of senior medical consultants. This underlines the importance of studying long work hours among senior medical consultants. In the general Danish population, $10.9 \%$ are registered as having redeemed $\mathrm{AD}$ drug prescriptions on average during 2008-2009 (33) compared to $2.8 \%$ among the senior medical consultants. The proportion of senior medical consultants redeeming $\mathrm{AD}$ drug prescriptions is most likely an underestimation for various reasons discussed under strengths and limitations of this study.

\section{Interpretation of findings}

The present study does not support the anticipation that long work hours increase the risk of depression when measured as redemption of $\mathrm{AD}$ drug prescriptions among Danish senior medical consultants. If anything, long weekly work hours vaguely appear to decrease the risk of redeeming $\mathrm{AD}$ drug prescriptions. Three explanations should help to understand this finding. Firstly, it is a known phenomenon in occupational epidemiology that, against all expectations, the risk of an undesired outcome tends to decline at high levels of exposure in exposure-response curves because of the healthy worker effect $(29,30)$. Senior medical consultants with mental health problems might have reduced their work hours, withdrawn from their position as a consultant, or been excluded by the criteria of no redemption of AD drug prescription at study entry. Secondly, taking the main finding on its face value, long work hours would actually be beneficial for the senior medical consultants. Senior medical consultants are expected to have relatively influential positions in that they are employed without an upper time period of employment (31). Furthermore, it can be speculated that the appeal of working long hours could be related to the fact that senior medical consultants are happy with the work that they do, they thrive on it and have surplus energy for it, which would counteract the risk of developing depres-

Table 3. Cox regression analysis of work hours and redemption of anti-depressive (AD) drug prescription. [HR=hazard ratio; $95 \% \mathrm{Cl}=95 \%$ confidence interval.]

\begin{tabular}{|c|c|c|c|c|c|c|c|c|}
\hline Hours & $\mathrm{N}$ & $\%$ & $\begin{array}{l}\text { Follow-up } \\
\text { (months) }\end{array}$ & $\begin{array}{c}\text { Number of } \\
\text { events }\end{array}$ & $\begin{array}{c}\mathrm{HR} \\
\text { (crude) }\end{array}$ & $95 \% \mathrm{Cl}$ & $\mathrm{HR}^{\mathrm{a}}$ & $95 \% \mathrm{Cl}$ \\
\hline $25-36$ hours & 126 & 4.5 & 16.7 & 3 & 0.88 & $0.27-2.91$ & 0.83 & $0.24-2.82$ \\
\hline 37-40 hours (reference) & 888 & 31.8 & 17.3 & 25 & 1.00 &.$\cdot$ & 1.00 & .. \\
\hline 41-44 hours & 743 & 26.6 & 17.2 & 24 & 1.15 & $0.66-2.02$ & 0.95 & $0.50-1.77$ \\
\hline 45-49 hours & 569 & 20.4 & 17.5 & 16 & 0.99 & $0.53-1.85$ & 0.88 & $0.43-1.78$ \\
\hline 50-54 hours & 260 & 9.3 & 17.5 & 7 & 0.95 & $0.40-2.19$ & 0.83 & $0.32-2.14$ \\
\hline $55-59$ hours & 121 & 4.3 & 17.4 & 3 & 0.88 & $0.26-2.91$ & 0.67 & $0.15-2.94$ \\
\hline$\geq 60$ hours & 83 & 3 & 17.6 & 1 & 0.42 & $0.06-3.11$ & 0.48 & $0.06-3.68$ \\
\hline
\end{tabular}

a Adjusted for gender, age, marital status, medical specialty, decision authority at work, social support at work, quantitative work demands and previous redemption of $A D$ drug prescription. 
Table 4. Cox regression analysis of work hours as a continious variable and redemption of anti-depressive (AD) drug prescription. [HR=hazard ratio]

\begin{tabular}{|c|c|c|c|}
\hline \multicolumn{2}{|c|}{ Crude } & \multicolumn{2}{|c|}{ Adjusted ${ }^{\mathrm{a}}$} \\
\hline $\mathrm{HR}$ & $95 \% \mathrm{Cl}$ & $\mathrm{HR}$ & $95 \% \mathrm{Cl}$ \\
\hline 0.95 & $0.80-1.12$ & 0.93 & $0.76-1.13$ \\
\hline
\end{tabular}

a Adjusted for gender, age, marital status, medical specialty, decision authority and social support at work, quantitative work demands, and previous redemption of $\mathrm{AD}$ drug prescription.

Table 5. Cox regression analysis of modifying effects of decision authority at work and social support at work, quantitative work demands and medical specialty on the effect of work hours on anti-depressive (AD) drug prescription. [HR=hazard ratio; 95\% $\mathrm{Cl}=95 \%$ confidence interval.]

\begin{tabular}{lcc}
\hline Modifying variables & $\mathrm{HR}^{\mathrm{a}}$ & $95 \% \mathrm{Cl}$ \\
\hline Work hours X decision authority at work X & 0.90 & $0.70-1.15$ \\
social support at work & & \\
Work hours X quantitative work demands & 0.95 & $0.75-1.21$ \\
Work hours X internal medicine & 1.40 & $0.58-3.41$ \\
Work hours X psychiatry $^{\mathrm{b}}$ & 1.78 & $0.70-4.50$ \\
Work hours X surgery $^{\mathrm{b}}$ & 1.14 & $0.44-2.93$ \\
\hline
\end{tabular}

a Adjusted for gender, age, marital status, medical specialty, decision authority and social support at work, quantitative work demands, and previous redemption of $\mathrm{AD}$ drug prescription.

${ }^{b}$ Reference: medical specialty (laboratory testing).

sion. Or senior medical consultants may master coping strategies to respond to the potential negative effect of long work hours when it comes to the risk of developing depression. Thirdly, influence by chance may explain the main finding.

\section{Earlier studies}

Most earlier studies reported an increased risk of depression or poor mental health in relation to working long hours regardless of statistical significance (10-16, 19, $22,24)$, while a few studies are consistent with findings of the present study $(9,13,18)$. Two studies reported no association $(17,20)$. Associations in the earlier studies did not seem to be related to any specific occupation or type of work. The possible modifying effects of decision authority and social support at work, quantitative work demands, and medical specialty on the association between long work hours and depression were not examined in earlier studies. However, some studies have shown that the intensity and type of work can modify the effect of work factors on mental health $(13,34)$.

\section{Strengths and limitations}

Measuring a disorder that is recurrent, even after several years, makes it debatable to what extent long work hours actually preceded redemption of $\mathrm{AD}$ drug prescriptions among senior medical consultants. Moreover, senior medical consultants seemingly free of having redeemed $\mathrm{AD}$ drug prescriptions before study entry could have redeemed $\mathrm{AD}$ drug prescriptions prior to the start of the study but would not have been registered if they redeemed such prescriptions before 1995 when the Medical Products Agency did not yet have a registry. However, considering that a person with depression is expected to recover after six months to one year (26), and that previous redemption of AD drug prescriptions was taken into account as a confounder, a relatively clear temporal direction between long work hours and redemption of $\mathrm{AD}$ drug prescriptions was expected.

Large contrast in work hours among the senior medical consultants enabled identification of a differentiated relationship, if any, and examining reported average work hours, made it possible to take high and low peak work periods into account. Furthermore, information on work hours was retrieved efficiently by means of the questionnaire survey. However, the work hour measurement has its limitations.

Work hours were only measured at one point in time. Moreover, long work hours naturally decrease time for other activities - for instance, responding to the questionnaire survey. However, bearing in mind that late respondents are not necessarily representative of nonrespondents, the non-response analysis did not indicate under-representation of senior medical consultants with long work hours. Although, a response rate of $>61.7 \%$ would reduce concerns related to non-response. Finally, some senior medical consultants may perceive long work hours as an expression of hard work and commitment. Others may regard them as a reflection of poor planning and coordination skills and disengagement from other life activities, which would not indicate a balanced worker. Both perceptions could trigger senior medical consultants to fabricate their statements of work hours to more or fewer hours than they actually work. However, since senior medical consultants are employed without an upper time period of employment, it is a central part of their work description to work according to the assignment. This implies finishing the assignment, regardless of the time taken to solve it. Also, the purpose of the questionnaire survey was not considered to be loaded in a direction that would trigger socially desirable answers. Therefore, an unfortunate impact of differing perceptions on long work hours is not considered as a large issue.

The use of registry information for outcome ascertainment enabled complete follow-up and excluded the possibility of respondent memory and interviewer bias. However, measuring a disorder like depression by means of redemption of $\mathrm{AD}$ drug prescriptions is not without its limitations. 
Firstly, redemption of AD prescription is a crude proxy of depression as evidenced by a differing prevalence between redemption of $\mathrm{AD}$ prescription compared to clinical depression (35) creating uncertainty about whether depression is really measured.

Secondly, AD drugs are also prescribed for disorders such as anxiety, obsessive-compulsive disorder, eating disorders, pain, and insomnia (21), which reduces clarity on whether the senior medical consultants' redemption of $\mathrm{AD}$ drug prescriptions were for depression or another disorder.

Thirdly, feeling depressed could have deterred senior medical consultants from taking part in the questionnaire survey despite being under treatment with $\mathrm{AD}$ drugs simply because depression is a disorder that reduces energy and motivation for taking part in life activities (36). The non-response analysis showed that non-respondents had a higher redemption of AD drug prescriptions than respondents, supporting concern about an underestimation of senior medical consultants redeeming $\mathrm{AD}$ drug prescriptions.

Fourthly, some senior medical consultants might not redeem $\mathrm{AD}$ drug prescriptions despite suffering from depression, resulting in an underestimation and/or misclassification of the outcome. Four possible reasons for this are considered: (i) senior medical consultants with mild or moderate depressions could have gone undetected because these depressions are usually not tackled with $\mathrm{AD}$ drugs (37); (ii) some medical consultants may not have admitted to themselves that they are depressed due to social stigma, shame, exclusion (36), or difficulties with identifying themselves as patients and not treatment providers; (iii) senior medical consultants could have obtained access to AD drugs circumventing the pharmacy system; (iv) long work hours may have an impact on the behavior of the medical consultants in terms of delaying seeking medical care and/or retrieving prescribed drugs. However, considering that medical consultants have expert knowledge on the consequences of not seeking medical care in time, this is not thought of as being a large issue.

Fifthly, senior medical consultants may have resigned or been laid off from their work at study entry during the follow up period. Following the senior medical consultants with a register-based tool would not capture this information. The issues related to misclassification are not expected to be related to work hours and if anything, may cause attenuation of risk estimates.

The main result of this study cannot be generalized to other occupations and in particular not to groups that are less privileged than medical consultants in terms of their socioeconomic position.

In conclusion, this study does not support the anticipation that long work hours increase the risk of depression. If anything, the results vaguely indicate that long weekly work hours decrease the risk of redeeming AD drug prescriptions among senior medical consultants. Most likely, this main result is explained by the healthy worker effect, but other potential explanations could be an unexpected protective effect of long work hours or chance.

More studies on workers in occupations suspected of having long work hours as well as general working populations are worth conducting to understand better the relationship between long work hours and depression. It is important that future studies address the healthy worker effect and reverse causation, for example by means of restriction to incident hires (29).

\section{Acknowledgments}

The Association of Senior Medical Consultants, Department of Occupational and Environmental Medicine at Bispebjerg Hospital, Medical Products Agency Register, Statistics Denmark and Danish Data Protection Agency supported the study.

\section{References}

1. Caruso CC, Bushnell T, Eggerth D, Heitmann A, Kojola B, Newman K, et al. Long working hours, safety, and health: toward a national research agenda. Am J Ind Med. 2006;49:930-42. http://dx.doi.org/10.1002/ajim.20373.

2. Spurgeon A, Harrington JM, Cooper CL. Health and safety problems associated with long working hours: a review of the current position. Occup Environ Med. 1997;54:367-75. http:// dx.doi.org/10.1136/oem.54.6.367.

3. Sparks K, Cooper C, Fried Y, Shirom A. The effects of hours of work on health: A meta-analytic review. J Occup Organ Psychol. 1997;70:391-408. http://dx.doi. org/10.1111/j.2044-8325.1997.tb00656.x.

4. Dembe AE, Erickson JB, Delbos RG, Banks SM. The impact of overtime and long work hours on occupational injuries and illnesses: new evidence from the United States. Occup Environ Med. 2005;62:588-97. http://dx.doi.org/10.1136/ oem.2004.016667.

5. Artazcoz A, Cortés I, Borrell C, Escribà-Agüir V, Cascant L. Gender perspective in the analysis of the relationship between long workhours, health and health-related behaviour. Scand J Work Environ. 2007;33(5):344-350. http://dx.doi. org/10.5271/sjweh.1154.

6. Hilton MF, Whiteford HA, Sheridan JS, Cleary CM, Chant DC, Wang PS, et al. The prevalence of psychological distress in employees and associated occupational risk factors. J Occup Environ Med. 2008;50:746-57. http://dx.doi.org/10.1097/ JOM.0b013e31817e9171.

7. Raediker B, JanBen D, Schomann C, Nachreiner F. Extended 
working hours and health. Chronobiol Int. 2006;23(6):130516. http://dx.doi.org/10.1080/07420520601096245.

8. Rosta J, Gerber A. Excessive working hours and health complaints among hospital physicians: a study based on a national sample of hospital physicians in Germany. Ger Med Sci. 2007;5:1-9.

9. Allen HM, Slavin T, Bunn WB. Do long workhours impact health, safety and productivity at a heavy manufacturer? J Occup Environ Med. 2007;49:148-71. http://dx.doi. org/10.1097/JOM.0b013e31802f09ee.

10. Andrea H, Bültmann U, van Amelsvoort LGPM, Kant Y. The incidence of anxiety and depression among employees - the role of psychosocial work characteristics. Depress Anxiety. 2009;26:1040-8. http://dx.doi.org/10.1002/da.20516.

11. Artazcoz L, Cortés I, Escribà-Agüir V, Cascant L, Villegas R Understanding the relationship of long working hours with health status and health-related behaviours. J of Epidemiol Commun H. 2009;63:521-7. http://dx.doi.org/10.1136/ jech.2008.082123.

12. Date Y, Abe Y, Aoyagi K, Ye Z, Takamura N, Tomita M, et al. Depressive symptoms in Chinese factory workers in Nagasaki, Japan. Ind Health. 2009;47:376-82. http://dx.doi. org/10.2486/indhealth.47.376.

13. Geiger-Brown J, Muntaner C, Lipscomb J, Trinkoff A. Demanding work schedules and mental health in nursing assistants working in nursing homes. Work Stress. 2004;18(4):292-304. http://dx.doi.org/10.1080/0267837041 2331320044.

14. Grosch JW, Caruso CC, Rosa RR, Sauter SL. Long hours of work in the U.S.: associations with demographic and organizational characteristics, psychosocial working conditions, and health. Am J Ind Med. 2006;49:943-52. http:// dx.doi.org/10.1002/ajim.20388.

15. Kleppa E, Sanne B, Tell GS. Working overtime is associated with anxiety and depression: the hordaland health study. J Occup Environ Med. 2008;50:658-66. http://dx.doi. org/10.1097/JOM.0b013e3181734330.

16. Nagashima S, Suwazono Y, Okubo Y, Uetani M, Kobayashi E, Kido T, et al. Working hours and mental and physical fatigue in Japanese workers. Occ Med. 2007;57:449-52. http://dx.doi. org/10.1093/occmed/kqm047.

17. Otsuka Y, Sasaki T, Iwasaki K, Mori I. Working hours, coping skills, and psychological health in Japanese daytime workers. Ind Health. 2009;47:22-32. http://dx.doi.org/10.2486/ indhealth.47.22.

18. Shields M. Long working hours and health. Health Rep. 1999;11(2):33-48.

19. Suwazono Y, Okubo Y, Kobayashi E, Kido T, Nogawa K. A follow-up study on the association of working conditions and lifestyles with the development of (perceived) mental symptoms in workers of a telecommunication enterprise. Occ Med. 2003;53(7):436-42. http://dx.doi.org/10.1093/occmed/ kqg102.

20. Wang J, Schmitz N, Dewa C, Stansfield S. Changes in perceived job strain and the risk of major depression: results from a population-based longitudinal study. Am J Epidemiol. 2009;169(9):1085-91. http://dx.doi.org/10.1093/aje/kwp037.

21. Michélsen H, Bildt C. Psychosocial conditions on and off the job and psychological ill health: depressive symptoms, impaired psychological wellbeing, heavy consumption of alcohol. J Occup Environ Med. 2003;60:489-496. http:// dx.doi.org/10.1136/oem.60.7.489

22. Tarumi K, Hagihara A, Morimoto K. A Prospective Observation of Onsets of Health Defects Associated with Working Hours. Ind Health. 2003;41:101-8. http://dx.doi. org/10.2486/indhealth.41.101.

23. De Raeve L, Jansen NWH, Kant I. Health effects of transitions in work schedule, workhours and overtime in a prospective cohort study. Scand J Work Environ Health. 2007;33(2):105113. http://dx.doi.org/10.5271/sjweh.1113.

24. Virtanen M, Ferrie JE, Singh-Manoux A, Shipley MJ, Stansfeld SA, Marmot MG, et al. Long working hours and symptoms of anxiety and depression: a 5-year follow-up of the Whitehall II study. Psychol Med. 2011;41:2485-94. http:// dx.doi.org/10.1017/S0033291711000171

25. Bildt $\mathrm{C}$, Michélsen $\mathrm{H}$. Gender differences in the effects from working conditions on mental health: a 4-year follow-up. Int Arch Occup Environ Health. 2002;75:252-8. http://dx.doi org/10.1007/s00420-001-0299-8.

26. Informatum. [Medicine.dk 2010]. København: Informatum A/S. 2010. Danish

27. Danmarks Statistik. Kvinder går 50 pct. mere til læge end mænd [Women visit the doctor 50\% more than men]. In Nyt fra Danmarks Statistik. Available from: http://www.dst.dk/ pukora/epub/Nyt/2005/NR353.pdf. Danish.

28. Karasek R. Job demands, job decision latitude, and mental strain: implications for job redesign. Admin Sci Q. 1979;24:285-308. http://dx.doi.org/10.2307/2392498.

29. Applebaum KM, Malloy EJ, Eisen EA. Reducing healthy worker survivor bias by restricting date of hire in a cohort study of Vermont granite workers. Occup Environ Med. 2007;64:681-7. http://dx.doi.org/10.1136/oem.2006.031369.

30. Stayner L, Steenland K, Dosemeci M, Hertz-Picciotto I. Attenuation of exposure-response curves in occupational cohort studies at high exposure levels. Scand J Work Environ. 2003;29(4):317-24. http://dx.doi.org/10.5271/sjweh.737.

31. Overlægeforeningen. Overenskomst for Overlæger 2011-2013[Collective Agreements for Senior Medical Consultants 2011-2013]. 2011. Available from: http:/www. laeger.dk/portal/page/portal/LAEGERDK/Laegerdk/ F_A_S/Ansat\%20i\%20region/Over1\%C3\%A6ger\%20 og\%201\%C3\%A6gelige $\% 20$ chefer/Overenskomst/ Overenskomst $\% 20$ for $\% 20$ over $1 \%$ C $3 \%$ A 6 ger $\% 20$ DOK532541.pdf.

32. Danmarks Statistik. [Work Time]. In Arbejdskraftundersøgelsen (AKU06). 2011. Available from: http://www.statistikbanken. $\mathrm{dk} / \mathrm{statbank} 5 \mathrm{a} / \mathrm{default} . \mathrm{asp} ? \mathrm{w}=1280$.

33. Lægemiddelstatistik. [Statistics for Drugs and Drug Categories, 2005-2009]. 2010. Available from: http://www. medstat.dk.

34. Schabracq MJ, Winnubst JAM, Cooper CL. The handbook of 
work and health psychology. 2nd ed. Chichester: J. Wiley \& Sons; 2003.

35. Bonde JP, Munch-Hansen T, Wieclaw J, WestergaardNielsen N, Agerbo E. Psychosocial work environment and antidepressant medication: a prospective cohort study. BMC Public Health. 2009;9:262. http://dx.doi.org/10.1186/14712458-9-262.
36. World Health Organization. The world health report: 2001: mental health: new understanding, new hope. Geneva: World Health Organization; 2001.

37. Sundhedsstyrelsen. [Referenceprogramme for unipolar depression in adults]. København: Sundhedsstyrelsen. 2007.

Received for publication: 5 August 2011

\section{Appendix. Supplementary tables A and B}

Table A. Characteristics of respondents compared to non- or late-respondents, categorical variables. [AD=anti-depressive.]

\begin{tabular}{|c|c|c|c|c|c|c|}
\hline \multirow[t]{2}{*}{ Characteristic } & \multicolumn{2}{|c|}{$\begin{array}{l}\text { Respondents } \\
(\mathrm{N}=2790)\end{array}$} & \multicolumn{2}{|c|}{$\begin{array}{c}\text { Non-respondents } \\
(\mathrm{N}=1418)\end{array}$} & \multicolumn{2}{|c|}{$\begin{array}{l}\text { Late-respondents } \\
\quad(\mathrm{N}=400)\end{array}$} \\
\hline & $\mathrm{N}$ & $\%$ & $\mathrm{~N}$ & $\%$ & $\mathrm{~N}$ & $\%$ \\
\hline \multicolumn{7}{|l|}{ Work hours } \\
\hline 25-36 hours & 126 & 4.5 & No data & No data & 29 & 7.2 \\
\hline $37-40$ hours & 888 & 31.8 & No data & No data & 138 & 34.5 \\
\hline 41-44 hours & 743 & 26.6 & No data & No data & 109 & 27.2 \\
\hline 45-49 hours & 569 & 20.4 & No data & No data & 71 & 17.7 \\
\hline 50-54 hours & 260 & 9.3 & No data & No data & 28 & 7 \\
\hline $55-59$ hours & 121 & 4.3 & No data & No data & 15 & 3.7 \\
\hline$\geq 60$ hours & 83 & 3 & No data & No data & 10 & 2.5 \\
\hline \multicolumn{7}{|c|}{ Redemption of $A D$ drug prescription } \\
\hline Yes & 79 & 2.8 & 45 & 3.2 & No data & No data \\
\hline No & 2711 & 97.2 & 1373 & 96.9 & No data & No data \\
\hline \multicolumn{7}{|l|}{ Gender } \\
\hline Men & 1977 & 70.9 & 1049 & 74 & No data & No data \\
\hline Women & 813 & 29.1 & 369 & 26 & No data & No data \\
\hline \multicolumn{7}{|l|}{ Marital status } \\
\hline Married & 2296 & 82.3 & 1131 & 79.8 & No data & No data \\
\hline Unmarried & 165 & 5.9 & 100 & 7.1 & No data & No data \\
\hline Divorced & 259 & 9.3 & 130 & 9.2 & No data & No data \\
\hline Widow/widower & 35 & 1.3 & 26 & 1.8 & No data & No data \\
\hline Missing values & 35 & 1.3 & 31 & 2.2 & No data & No data \\
\hline \multicolumn{7}{|l|}{ Work specialty } \\
\hline Internal medicine & 1187 & 42.5 & No data & No data & 75 & 35.9 \\
\hline Surgery & 798 & 28.6 & No data & No data & 71 & 34 \\
\hline Psychiatry & 238 & 8.5 & No data & No data & 31 & 14.8 \\
\hline Laboratory testing & 361 & 12.9 & No data & No data & 32 & 15.3 \\
\hline Missing values & 206 & 7.4 & No data & No data & 191 & 47.7 \\
\hline \multicolumn{7}{|c|}{ Previous redemption of $A D$ drug prescription } \\
\hline Yes & 308 & 11 & 175 & 12.3 & No data & No data \\
\hline No & 2482 & 89 & 1243 & 87.7 & No data & No data \\
\hline
\end{tabular}

Table B. Characteristics of respondents compared to non- or late-respondents, continuous variables. [SD=standard deviation; Min=minimum; Max=maximum.]

\begin{tabular}{|c|c|c|c|c|c|c|c|c|c|c|c|c|}
\hline \multirow[t]{2}{*}{ Characteristic } & \multicolumn{4}{|c|}{$\begin{array}{c}\text { Respondents } \\
(\mathrm{N}=2790)\end{array}$} & \multicolumn{4}{|c|}{$\begin{array}{c}\text { Non-respondents } \\
(\mathrm{N}=1418)\end{array}$} & \multicolumn{4}{|c|}{$\begin{array}{l}\text { Late-respondents } \\
\qquad(\mathrm{N}=400)\end{array}$} \\
\hline & Mean & SD & Min & Max & Mean & SD & Min & $\operatorname{Max}$ & Mean & SD & Min & Max \\
\hline Age & $54.5^{\mathrm{a}}$ & $43.4^{b}$ & 36 & 80 & 55 & 48.4 & 36 & 79 & No data & No data & No data & No data \\
\hline Decision authority at work & 3.3 & 0.8 & 1 & 5 & No data & No data & No data & No data & 3.3 & 0.9 & 1 & 5 \\
\hline Social support at work & 3.4 & 1 & 1 & 5 & No data & No data & No data & No data & 3.4 & 1 & 1 & 5 \\
\hline Quantitative work demands & 3.2 & 0.8 & 1 & 5 & No data & No data & No data & No data & 3.2 & 0.8 & 1 & 5 \\
\hline
\end{tabular}

a Median.

b Variance. 